\title{
Yenilenmiş Bloom Taksonomisine Göre Analiz Örneği: 2017 Taslak Ortaöğretim Kimya Dersi Öğretim Programı
}

\author{
Analysis of A Sample According to the Revised Bloom Taxonomy: The Draft \\ Line Curriculum of Secondary School Chemistry 2017
}

\section{Seraceddin Levent ZORLUOĞLU * Çağrı GÜVEN ** Zehra Sedef KORKMAZ ${ }^{* * *}$}

\begin{abstract}
$\ddot{O}_{z}:$ Bu çalışmanın amacı T.C. Milli Eğitim Bakanlığı Ortaöğretim Genel Müdürlüğü tarafından yayınlanan 2017 yılı Taslak Ortaöğretim Kimya Dersi Öğretim Programı'nda yer alan kazanımların yenilenmiş Bloom taksonomisinin bilgi ve bilişsel süreç boyut basamaklarına göre hangi basamaklarda olduklarını tespit etmektir. Bu amaç doğrultusunda çalışma, nitel araştırma metodolojisi içerisinde yer alan doküman incelemesi kullanılarak gerçekleştirilmiştir. Taslak Ortaöğretim Kimya Dersi Öğretim programında yer alan 129 kazanım betimsel analiz kullanılarak incelenmiştir. Verilerin analizinde güvenirlik hesaplamaları yapılmış ve güvenirlik katsayıları .70'den büyük bulunmuştur. Analiz bulgularına göre 2017 Taslak Ortaöğretim Kimya Dersi Öğretim Programı kazanımlarının bilgi boyutlarına homojen olarak dağılmadığı tespit edilmiştir. Bilgi boyutunda; en çok kavramsal bilgi düzeyinde kazanıma, en az ise üstbilişsel bilgi düzeyinde kazanıma yer verildiği belirlenmiştir. Ayrıca kazanımların genel olarak bilişsel süreç boyutu basamaklarına da homojen olarak dağılmadığı belirlenmiş̧tir. Bilişsel süreç boyutunda; en çok anlama düzeyinde kazanıma, en az ise değerlendirme düzeyinde kazanıma yer verildiği belirlenmiștir. Taslak Ortaöğretim Kimya Dersi Öğretim Programı kazanımlarında üst düzey bilişsel süreç boyutlarına ve öğrenci öğrenmelerini aktif kılıcı üst düzey bilgi boyutuyla ilgi kazanımlara yeteri kadar yer verilmediği sonucuna ulaşılmıştır.
\end{abstract}

Anahtar sözcükler: Yenilenmiş Bloom Taksonomisi, Ortaöğretim Kimya Dersi Öğretim Programı

\begin{abstract}
The aim of this study was to determine in which phase the learning outcomes of the secondary school chemistry curriculum draft line of 2017, published by the Ministry of Education, secondary schools deputy general manager, accords with the knowledge and cognitive duration aspect phase of the revised Bloom taxonomy. Accordingly, this study was conducted through document review employing a qualitative research methodology. 129 outcomes were analysed through descriptive analysis. While analysing this data, confidence calculations were made and the confidence coefficients were found to be greater than .70. From these findings, the outcomes for the draft line curriculum for secondary school chemistry 2017 were not distributed homogenously through the knowledge dimensions. Concerning the knowledge dimension, it was determined that the dimension outcome, at least the metacognitive knowledge outcome, was given enough place. Furthermore, it is stated that generally the outcomes are not distributed non-homogenously in the cognitive duration dimension phases. For the cognitive dimension, it was found that mostly the comprehension level outcome, at least the evaluation level outcome was given enough place. On the draft line of the Secondary School Chemistry Curriculum outcomes, it was found that neither the metacognitive duration dimensions nor this together with the high level knowledge dimensions on interest outcomes for activating student participation was given enough place.
\end{abstract}

Keywords: Revised Bloom Taxonomy, Curriculum of Secondary School Chemistry.

\footnotetext{
*Yrd. Doç. Dr., Süleyman Demirel Üniversitesi, Eğitim Fakültesi, Isparta. seraceddinzoroglu @ sdu.edu.tr

** Fen Bilimleri Öğretmeni, TOKİ Şehit Jandarma Er Osman Öden Ortaokulu, Kırıkkale. c-guven @ hotmail.com

**** Arş. Gör., Artvin Çoruh Üniversitesi, Eğitim Fakültesi, Artvin. zehrasedefcoskun@gmail.com
} 


\section{Giriş}

Eğitim sisteminde, fen bilimleri üç temel disiplin olan fizik, kimya ve biyolojiyi içermektedir (Ayas et al. 1997). Bu disiplinlerden kimya, maddelerin yapı, özellik ve birbirleriyle etkileşimlerini araştırmaktadır. Kimya, günümüzde canlıların yapısını anlamaktan çevre problemlerinin çözümüne kadar farklı alanlarda kullanılmaktadır (Pamuk 1988). Kimya öğretimi, öğretim programına konulması gereken uygun kazanımların olması ve kazanımların bir amaç içinde planlı biçimde yürütülmesiyle sağlanabilir (Zorluoğlu et al. 2016). İyi bir kimya öğretimi, iyi bir öğretim programıyla mümkündür. Bunun şartlarından biri de uygun kazanımların programda olmasidir.

Öğretim programı, okulda ve okul dışında öğrenene kazandırılması planlanmış dersin öğretimiyle alakalı etkinliklerin tamamını kapsayan yaşantılar düzeneğidir (Demirel 2012). Geçmişten günümüze değişik dönemlerde farklı öğretim programlarının uygulamaları olmuştur. Bazı dönemlerde tek bir öğretim programı tüm okullarda uygulanırken, bazı dönemlerde ise okulun türü ve öğrencilerin özellikleri dikkate alınıp uygulanmıştır. Günümüzde kimya dersi öğretim programı, okul farkı gözetmeksizin, liselerde uygulanmaktadır (Akaygün et al. 2016). Gelişimlerini sürdürmek isteyen ülkeler, fen bilimleri eğitiminin niteliğini artırmak için yaptıkları çalışmalarda genellikle müfredat programlarının iyileştirilmesi ve etkin biçimde yürütülmesi üzerinde yoğunlaşmaktadır (Ayas 1995). Son zamanlarda yapılan öğretim programları, öğrenciye zengin öğrenme yaşantısı temin etmek, zamanın gerekliliklerine göre eğitmek için dünya genelinde eğitim yeniliklerine uygun biçimde hazırlanmaya çalışılmaktadır (Ekiz 2008). Bu doğrultuda taslak Kimya Dersi Öğretim Programı; çağdaş öğrenme-öğretme yöntemlerini bulundurmayı, uygulamaya ve araştırmaya olanak sağlamayı, bilim çalışmalarına merak uyandırmayı, projeleri desteklemeyi, teknolojiyle teorik olguları sağlamlaştırmayı, öğretmen öğrenci iletişimini basitleştirmeyi, küresel çapta bilimsel çalışmalara imkân sağlamayı, üretici düşünmeye destek veren eğitim yaratmaya rehber olmayı hedeflemektedir (MEB 2017). Öğretimin niteliğiyle doğrudan alakası olmasından dolayı, öğretim programındaki kazanımların, yenilenmiş Bloom taksonomisinin bilgi ve bilişsel süreç boyutları açısından uygun basamaklarda hazırlanmış olması beklenir (Anderson \& Krathwohl 2001). Beklenenin aksi bir durumla karşılaşılması durumda eksiklerin giderilmesi gerekmektedir. Kimya öğretmenleri, öğretim programını uygularken, kazanımların sınıflama tablosundaki yerlerini bilmeleri öğretimin amaçlar dahilinde planlı bir biçimde yürütülmesine yardımcı olmaktadır.

Eğitimin amaçlarını bilişsel, duyuşsal ve psiko-motor olarak ilk sınıflandıran, Benjamin Bloom ve arkadaşlarıdır (Doğanay \& Sarı 2007). Sınıflandırma, öğretim sürecinin bitiminde öğrenciden istenen davranışları kategorilendirmeye yarayan yapıdır (Krathwohl 2002). Bloom Taksonomisi, tek boyutludur; birikimli bir hiyerarşiye sahiptir; alt düzey basamakları bilgi, kavrama ve uygulama, üst düzey basamaklar ise analiz, sentez ve değerlendirmedir (Bloom, 1956). Mevcut hali ihtiyaçları karşılamada yetersiz kaldığı tartışma konusu olunca, 2001 yılında Bloom'un arkadaşları taksonomiyi yenilemişlerdir.

Yenilenen taksonomi, modern zamanın anlayışına uyum sağlamak için güncellenmiştir ve bundan dolayı dünyanın her yerinde kullanılabilir olacağı öngörülmektedir (Tutkun et al. 2015). Bümen (2006), Bloom'un ilk taksonomisinin yenilenme gerekçelerini iki şekilde ifade etmiştir: Bunlardan ilki eğitimcilerin dikkatini taksonomiye tekrar yöneltmek, ikincisi ise 1956 ve 2001 yılları arasında dünyadaki gelişmelerin, psikolojiden, eğitim ve öğretime kadar pek çok alana yansıması ve modern bilgilerin yenilenen taksonomiyle birleştirme ihtiyacının doğmasıdır.

Yenilenen Bloom taksonomisi, sınıflandırmaya önemli yenilikler getirmiştir; basamaklar anlaşılır ve kapsamlı bir biçimde ortaya konmuştur (Yüksel 2007). Kazanımların yazılmasını 
basitleştirerek, performans değerlendirmesini olanaklı hale getirmiştir (Tutkun et al. 2015). Ayrıca kazanımların iki boyutlu bir şekilde görülebileceği Taksonomi tablosunun oluşmasını sağlamıştır. Bu iki boyutun dikey sütununu bilgi birikim boyutu oluştururken yatay boyutunu ise bilişsel süreç boyutu oluşturur. Her iki boyutun çakıştı̆̆ yerler hücreleri oluşturmaktadır (Anderson 2005; Amer 2006; Krathwohl 2009). Öğretim programlarında her bir kazanım Taksonomi tablosu kullanılarak bir hücrede sınıflandırılabilir. $\mathrm{Bu}$ işlem için kazanım cümlesinde bulunan fiil, bilişsel süreç boyutunda yer alan basamaklara karşıllk gelirken isim ise bilgi birikim boyutunda yer alan basamaklara karşllık gelmektedir. Basamaklar arasında kesin ayırımlar olmayıp esnek geçişler olabilir (Anderson \& Krathwohl 2001).

Bilişsel süreç boyutu fiil yapısına dönüştürülmüş altı basamaktan oluşur (Anderson 2005). $\mathrm{Bu}$ basmaklar; hatırlama, ezberden, öğrenildiği gibi yorum yapmadan tekrarlanan davranışları (Sönmez 2007); anlama, öğrenilen yeni bilgiyi mevcut şemalarla bütünleştirmeyi (Mayer 2002); uygulama, alıştırma ve problem çözmek için işlemlerden yararlanmayı; çözümleme, bütünü oluşturan ögeleri ayırmayı ve ögelerin birbiri ve bütünle ilişkisini; değerlendirme, ölçüte dayalı yargıları (Anderson \& Krathwohl 2001); yaratma, ögeleri birleştirerek anlamlı ve özgün eserler oluşturmayı (Sönmez 2007) içerir.

Bilgi birikim boyutu dört basamaklıdır (Anderson \& Krathwohl 2001); olgusal bilgi, bir disiplinde yer alan problemleri çözebilmek için bilinmesi elzem olan temel ögeleri; kavramsal bilgi, sınıflamalar, ilkeler, kuramlar gibi organize edilmiş bilgiler arasındaki ilişkileri, bir konunun nasıl yapılandırıldığı ile ilgili bilgileri; işlemsel bilgi, yapılacak şeyin nasıl yapılabileceği ile alakalı bilgiyi; üstbilişsel bilgi, bireyin kendi bilişiyle alakalı bilgiye sahip olmayı içerir.

Kazanımların Taksonomi tablosuna yerleştirilememesinin nedenleri vardır. Bu nedenlerden biri cümlenin birden fazla fiil ve ad içermesi diğeri ise cümlede bulunan fiilin işaret ettiği ifadenin anlaşılamamasıdır (Anderson \& Krathwohl 2010). Yukarıda geçen nedenlerden dolayı kazanımların sınıflandırılmasında güçlükler yaşanabilmekte ve basamaklar arasında esnek geçişler söz konusu olabilmektedir.

$\mathrm{Bu}$ çalışmada, T.C. Milli Eğitim Bakanlığı Ortaöğretim Genel Müdürlüğü tarafından yayınlanmış, 2017 yılı Taslak Ortaöğretim Kimya Dersi Öğretim Programı'nda mevcut 129 kazanımın yenilenmiş Bloom taksonomisinin bilgi ve bilişsel süreç boyut basamaklarına göre hangi basamaklarda olduklarının tespit edilmesi amaçlanmıştır. Yapılan çalışmanın sonucunun, nihai programın kazanımlarının hazırlanmasında yardımcı olacağı düşünülmektedir. Söylenilen amaçlar çerçevesinde “Taslak Ortaöğretim Kimya Dersi Öğretim Programı'nda mevcut kazanımların, yenilenmiş Bloom taksonomisinin bilgi ve bilişsel süreç boyut basamakları açısından düzeyi ve eğilimi nasıldır?"' sorusu cevaplanmaya çalışılımıştır.

Çalışma bulgularının; kimya öğretmenleri başta olmak üzere, konuyla alakalı eğitimcilere kazanımların nasıl sınıflandırılacağını, öğrencilere etkili bir şekilde nasıl kazandırılacağını, her basamakla ilgili soruların nasıl sorulup değerlendirileceğini gösterecek nitelikte bir kılavuz olabileceği düşünülmektedir. Öğrencilerde istendik davranış özelliklerinin hangi basamakta olduğunu bilmeleri, kimya öğretmenlerine ders tasarlarken, konu anlatırken ve sonuç olarak dersin amacına ulaşması için fayda sağlayabileceği düşünülmektedir. Ayrıca nihai programda çalışma sonuçlarının dikkate alınması, kimya öğretmenlerine, bu konuda yapılacak çalışmalara ve program yazarlarına kazanım hazırlamada yarar sağlayacağı düşünülmektedir. 


\section{Araştırmanın Yöntemi}

Çalışma, nitel araştırma metodolojisi içerisinde yer alan doküman incelemesi kullanılarak gerçekleştirilmiştir. Doküman inceleme, olgularla ilgili olarak yayınlanmış kitap ve dergi gibi birtakım yazılı materyalleri analiz etmede kullanılan bir yöntemdir (Karasar 2008). Görüşme ve gözlem yapmanın mümkün olmadığı araştırmalarda, doküman incelemesi tek başına bir araştırma yöntemi olarak kullanılabilmektedir (Bowen 2009). Bu çalışmada doküman incelemesi, araştırılması hedeflenen olgu/lar hakkında bilgi içeren yazılı materyallerin analizini kapsaması ve araştırmanın amacına uygunluğu nedeniyle kullanılmıştır (Yıldırım \& Şimşek 2011). Çalışmada, yenilenmiş Bloom taksonomisine göre, 2017 yılında yayınlanan Ortaöğretim Kimya Dersi Öğretim Programı kazanımlarının dağılımını ortaya koymak amacıyla programda yer alan 129 kazanımın analizi yapılmıştır.

\section{Veri Analizi}

Çalışmada verilerin analizi, betimsel analiz yöntemi kullanılarak gerçekleştirilmiştir. Betimsel analizde, araştırmacı tarafından önceden belirlenmiş olan bazı temalara göre betimlemeler yapılır (Glesne 2013). Bu nedenle, çalışma kapsamında kazanımların yenilenmiş Bloom taksonomisine göre analizinde "yenilenmiş Bloom taksonomi basamakları" dikkate alınarak analiz yapıldığından betimsel analiz yöntemi tercih edilmiştir.

Analiz sürecinde araştırmacılar, kazanımların sınıflandırmasını yapabilmek için kazanımların fiil ifadeleri ve ad ifadelerini belirlemiş̧lerdir. Daha sonra fiil ifadesinin hangi Bilişsel Süreç Boyutuna yerleştirileceği ve ad ifadesinin hangi Bilgi Boyutuna yerleştirileceği tespit ederek kazanımın yenilenmiş Bloom taksonomisindeki yerini belirlemişlerdir.

Taslak Ortaöğretim Kimya Dersi Öğretim Programı kazanımlarının analizi bir kimya eğitimi, bir fen eğitimi ve bir program geliştirme uzmanı tarafından dört basamakta gerçekleştirilmiştir:

Birinci aşama, kazanımların yenilenmiş Bloom taksonomisine göre analizi konusunda deneyimli her bir araştırmacı tarafından 9. sınıfta yer alan "Kimya Bilimi”, "Atom ve Periyodik Sistem" ve "Kimyasal Türler Arası Etkileşimler" ünite kazanımlarının analizleri bireysel olarak yapılmıştır. İkinci aşama, ortak yargıya varılması amacıyla, bir araştırmacı tarafından her bir kazanım analizindeki görüş birliği ve görüş farkl11ı̆̆ belirlenerek araştırmacılar arası görüş farklılıklarının nedenleri tartışılmıştır. Bu amaçla kazanım analizinde boyutlarla ilgili görüş birliği sağlandığında, araştırmacıların belirlediği boyut seçilmiştir. Görüş birliği sağlanmadığında ise; üç araştırmacıdan en az bir araştırmacının diğer araştırmacılardan farklı bir boyut belirlediği durumda farklı boyutu belirleyen araştırmacı bu boyutu neden seçtiğini söylemiş ve araştırmacı ile görüş birliğine varılmaya çalışılmıştır. Görüş birliği sağlanılamadığ durum en çok tekrar edilen boyutun kazanım boyutu olarak belirlenmesine karar verilmiştir. Ü̧̧üncü aşama, analiz konusunda ortak yargıya varan araştırmacılar bireysel olarak birinci aşamada analizi yapılan kazanımlar dışındaki her bir kazanımı bireysel olarak analiz etmişlerdir. Dördüncü aşama, her bir araştırmacının yapmış olduğu analizler bir araştırmacı tarafından bir araya getirilmiş ve her bir kazanım analizindeki görüş birliği ve görüş farklılığı belirlenerek araştırmacılar arası görüş farklılıkları belirlenmiştir. Daha sonra ikinci aşamadaki yol izlenerek nihai olarak görüş birliği ve görüş ayrılığı olan kazanımlar tespit edilmiştir.

Analizin ikinci ve dördüncü basamağında kazanımlara yönelik "araştırmacılar arası görüş birliğ̈̈" ve "araştırmacılar arası görüş ayrılı̆̆ı" sayıları kullanılarak güvenirlik hesaplaması yapılmıştır. Analizin güvenirlik katsayısı, Miles ve Huberman'ın (1994) güvenirlik katsayısı formülünün kazanımlara adapte edilmesiyle oluşturulan "görüş birliğine varılan kazanım sayısl/ 
toplam kazanım sayısı" formülü (Zorluoğlu et al. 2017) kullanılarak hesaplanmıştır. Güvenirlik hesaplaması analiz sürecinin ikinci ve dördüncü aşamalarında her bir aşama için ayrı hesaplanmıştır. İkinci aşamada güvenirlik katsayısı .83 ve dördüncü aşamada ise güvenirlik katsayısı .72 olarak hesaplanmıştır. Yapılan hesaplamalar sonucunda he iki aşamada da kazanımların güvenirlik katsayısı .70 'den büyük olduğu için analizlerin güvenilir olduğu düşünülmektedir.

Araştırmacılar kazanımların yenilenmiş Bloom taksonomisine göre nasıl bir eğilim gösterdiğini belirlemek ve taksonomi tablosundaki yerinin belirleyebilmek amaciyla kazanımların ad ve fiil ifadeleri belirlemişlerdir. Daha sonra ad ve fiil ifadelerine göre kazanımların hangi bilgi boyutu ve bilişsel süreç boyutu alt basamaklara girdiği tespit edilerek, kazanımın Taksonomi tablosundaki yeri belirlenmiştir (Anderson \& Krathwohl 2001). Kazanımların yenilenmiş Bloom taksonomisine göre nasıl analiz edildiği ve yenilenmiş Bloom taksonomisi tablosuna (Tablo 1) nasıl yerleştirildiği ile ilgili birkaç örnek aşağıda sunulmuştur:

"9.1.1.1. Kimyanın bilim olma sürecini açıklar." kazanımında "Kimyanın bilim olma süreci” isim ifadesi öğrencilerin bilmek zorunda oldukları temel unsurları içerdiğinden bilgi boyutu basamaklarından olgusal bilgi; "açıklar" fiil ifadesi öğrencilerden kavramların açıklanmasını istediğinden dolayı bilişsel süreç boyutundan anlama boyutu seçilmiştir. Kazanım Tablo 1'de olgusal bilgi ve anlama basamaklarının kesiştiği A2 hücresine yerleştirilmiştir.

"9.5.1.1. Su kaynaklarının ve korunmasının önemini açıklar." kazanımının "su kaynaklarının ve korunmasının önemini" isim ifadesi bir yap1 içerisindeki temel unsurlar arasındaki karşılıklı ilişkilerle ilgili bilgi olduğu için kavramsal bilgi; "açıklar" fiil ifadesinde ise kavramların açıklanması istediğinden bilişsel süreç boyutundan anlama boyutu seçilmiştir. Kazanım Tablo 1'de kavramsal bilgi ve anlama basamaklarının kesiştiği B2 hücresine yerleştirilmiştir.

"11.4.3.1.Çözeltilerin koligatif özellikleri ile derişimleri arasında ilişki kurar.” kazanımının "çözeltilerin koligatif özellikleri ile derişimleri" isim ifadesi bir yapı içerisindeki temel unsurlar arasındaki karş1lıklı ilişkilerle ilgili bilgi olduğu için kavramsal bilgi; "ilişki kurar" fiil ifadesinde ise kavramların birbiri arasındaki ilişkilerin belirlenmesi gerektiğinden bilişsel süreç boyutundan çözümleme boyutu seçilmiş̧ir. Kazanım Tablo 1'de kavramsal bilgi ve çözümleme basamaklarının kesiştiği B4 hücresine yerleştirilmiştir.

"11.2.2.1. Kütle, mol sayısl, molekül sayısı, atom sayısı ve gazlar için normal şartlarda hacim kavramlarını birbirleriyle ilişkilendirerek hesaplamalar yapar." kazanımının "kütle, mol sayısı, molekül sayısı, atom sayısı ve gazlar için normal şartlarda hacim kavramlarını birbirleriyle ilişkilendirerek" isim ifadesi kavramlarla ilgili teknikleri ve metotları kullanma gerektirdiğinden işlemsel bilgi; "hesaplamalar yapar" fiil ifadesi matematik işlem becerisi kullanılarak hesaplama yapılması gerektirdiğinden dolayı bilişsel süreç boyutundan uygulama boyutu seçilmiştir. Kazanım Tablo 1'de işlemsel bilgi ve uygulama basamaklarının kesiştiği C3 hücresine yerleştirilmiştir. 
Tablo 1. Örnek Analizlerin Yenilenmiş Bloom Taksonomisi Tablosundaki Yeri

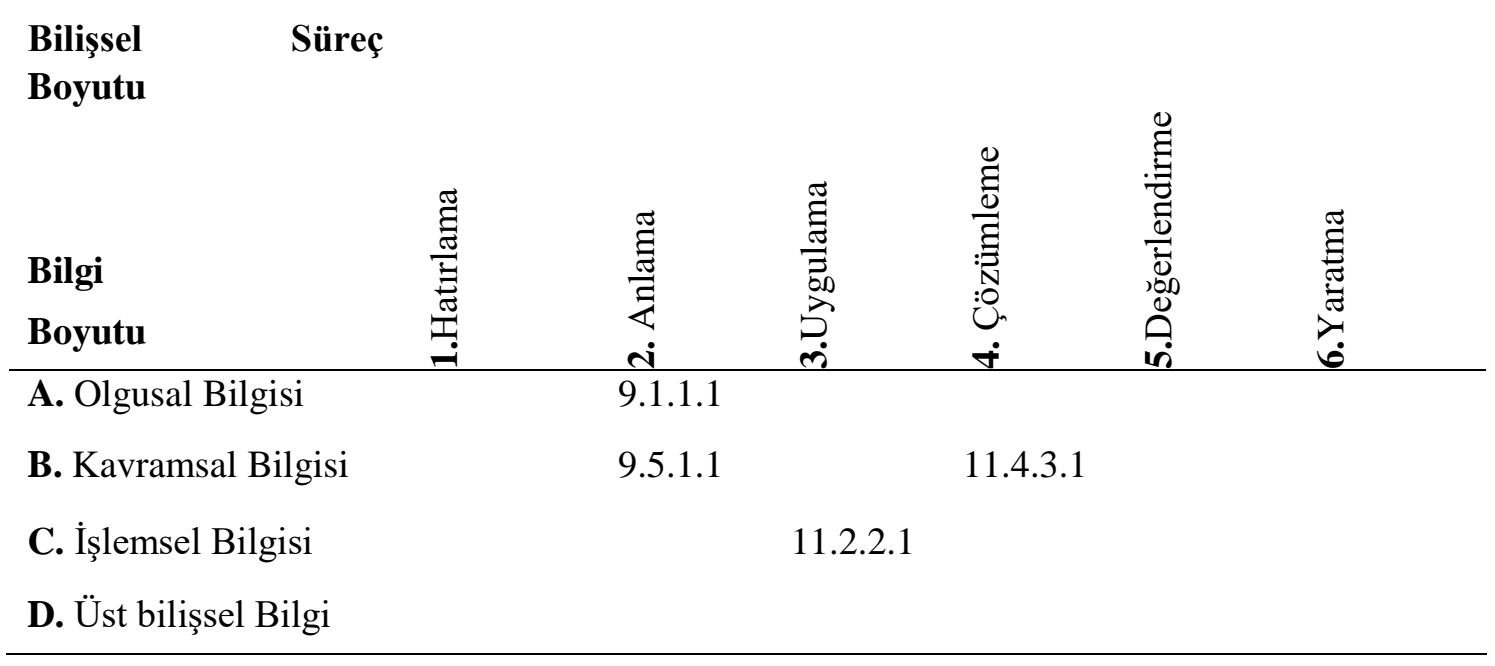

\section{Bulgular}

Çalışma kapsamında Taslak Ortaöğretim Kimya Öğretim Programında yer alan 129 kazanımın yenilenmiş Bloom taksonomisine göre analizi yapılmış ve kazanımların taksonomi tablosundaki yerleri tespit edilmiştir. Buna göre kazanımların 9., 10., 11 ve 12. sınıf düzeylerinde ve ortaöğretim düzeyinde yenilenmiş Bloom taksonomisinde yer alan boyutlar ve alt boyutlara göre dağılımının nasıl gerçekleştiğinin daha iyi görülebilmesi amacıyla Fig. 1-5 oluşturulmuştur.

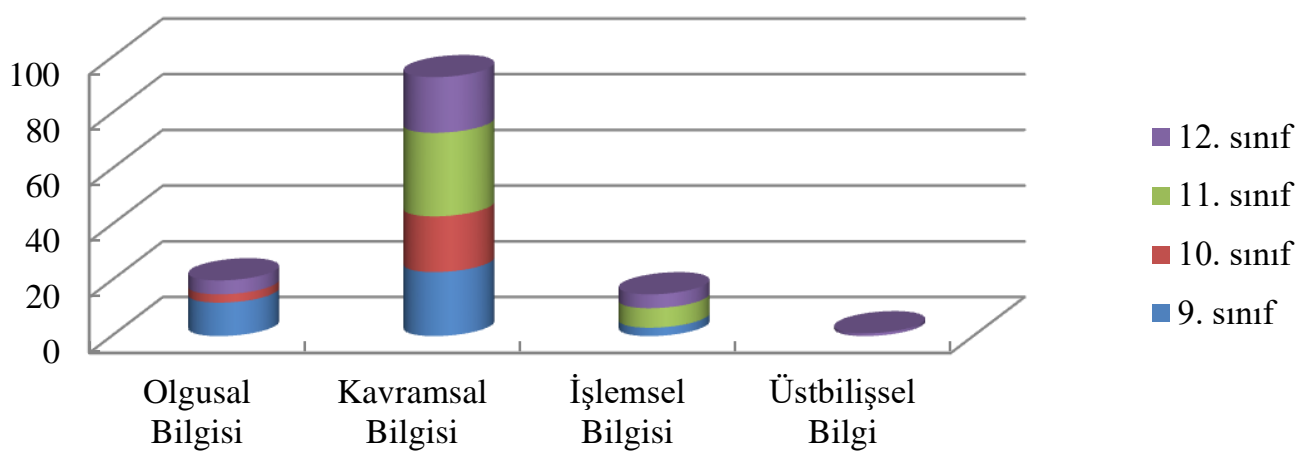

Fig. 1. Taslak Ortaöğretim Kimya Dersi Öğretim Programı Kazanımlarının Bilgi Boyutu Alt Basamaklarına Göre Dağıılımı

Taslak Ortaöğretim Kimya Dersi Öğretim Programı'nda yer alan kazanımların yenilenmiş Bloom taksonomisi bilgi boyutu alt basamaklarına göre dağılımı görülmektedir (Fig. 1). Genel olarak bakıldığında kazanımların bilgi boyutlarına homojen olarak dağılmadığı tespit edilmektedir (Fig. 1). Ayrıca kazanımların bilgi boyutu basamaklarına göre sınıflar düzeyinde dağılımına bakıldığında da, homojen bir dağılım göstermediği anlaşılmaktadır (Fig. 1). Taslak Ortaöğretim Kimya Dersi Öğretim Programı kazanımları bilgi boyutu basamaklarına göre değerlendirildiğinde, kazanımların \%15'i olgusal bilgi, \%72'si kavramsal bilgi, \%12'si işlemsel bilgi ve \%1'i üstbilişsel bilgi düzeyinde olduğu belirlenmiştir. Buna göre programda en az üst 
bilişsel bilgi düzeyine yönelik, en çok ise kavramsal bilgi düzeyine yönelik kazanımlara yer verildiği belirlenmiştir (Fig. 1).

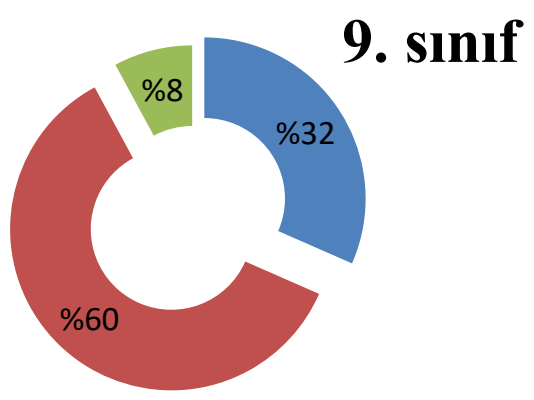

\author{
- Olgusal Bilgisi \\ - Kavramsal \\ Bilgisi
}

Fig. 2. Taslak Ortaöğretim Kimya Dersi Öğretim Programı 9. Sınıf Kazanımlarının Bilgi Boyutu Alt Basamaklarına Göre Yüzde Dağılımı

9. sınıf kazanımlarının \%60'1 kavramsal bilgi, \%32'si olgusal bilgi ve \%8'i işlemsel bilgi düzeyindedir (Fig. 2). 9. sınıf düzeyinde en çok kavramsal bilgi düzeyinde kazanım bulunurken, üstbilişsel bilgi düzeyinde hiçbir kazanım bulunmamaktadır.

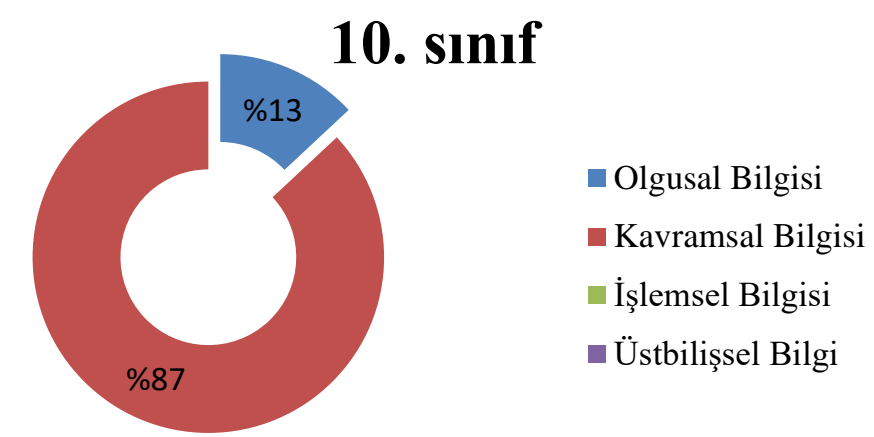

Fig. 3. Taslak Ortaöğretim Kimya Dersi Öğretim Programı 10. Sınıf Kazanımlarının Bilgi Boyutu Alt Basamaklarına Göre Yüzde Dağılımı

10. sınıf kazanımlarının \%87'si kavramsal bilgi ve \%13'ü olgusal bilgi düzeyindedir (Fig.3). 10. sınıf kazanımlarında işlemsel bilgi ve üstbilişsel bilgi düzeyinde hiçbir kazanım yer almamaktadır.

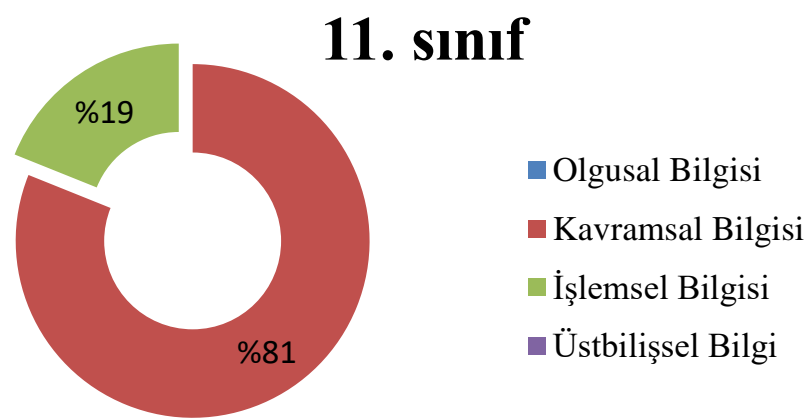

Fig. 4. Taslak Ortaöğretim Kimya Dersi Öğretim Programı 11. Sınıf Kazanımlarının Bilgi Boyutu Alt Basamaklarına Göre Yüzde Dağılımı

11. sinıf kazanımlarının \%81'i kavramsal bilgi ve $\% 19$ 'u olgusal bilgi düzeyindedir. 11. sınıf kazanımlarında da 10. sınıf kazanımlarındaki gibi işlemsel bilgi ve üstbilişsel bilgi düzeyinde 
hiçbir kazanım yer almamaktadır (Fig. 4).

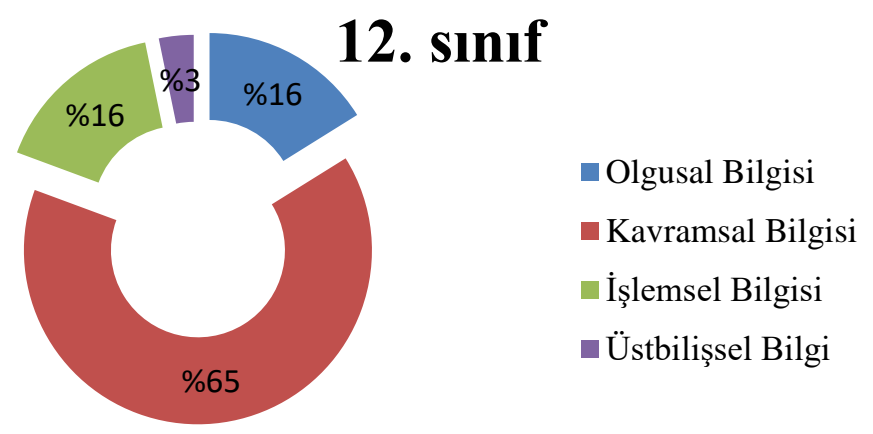

Fig. 5. Taslak Ortaöğretim Kimya Dersi Öğretim Programı 12. Sınıf Kazanımlarının Bilgi Boyutu Alt Basamaklarına Göre Yüzde Dağılımı

12. sınıf kazanımlarının \%65'i kavramsal bilgi, \%16'sı olgusal bilgi, \%16'sı işlemsel bilgi ve \%3’ü üstbilişsel bilgi düzeyindedir (Fig. 5).

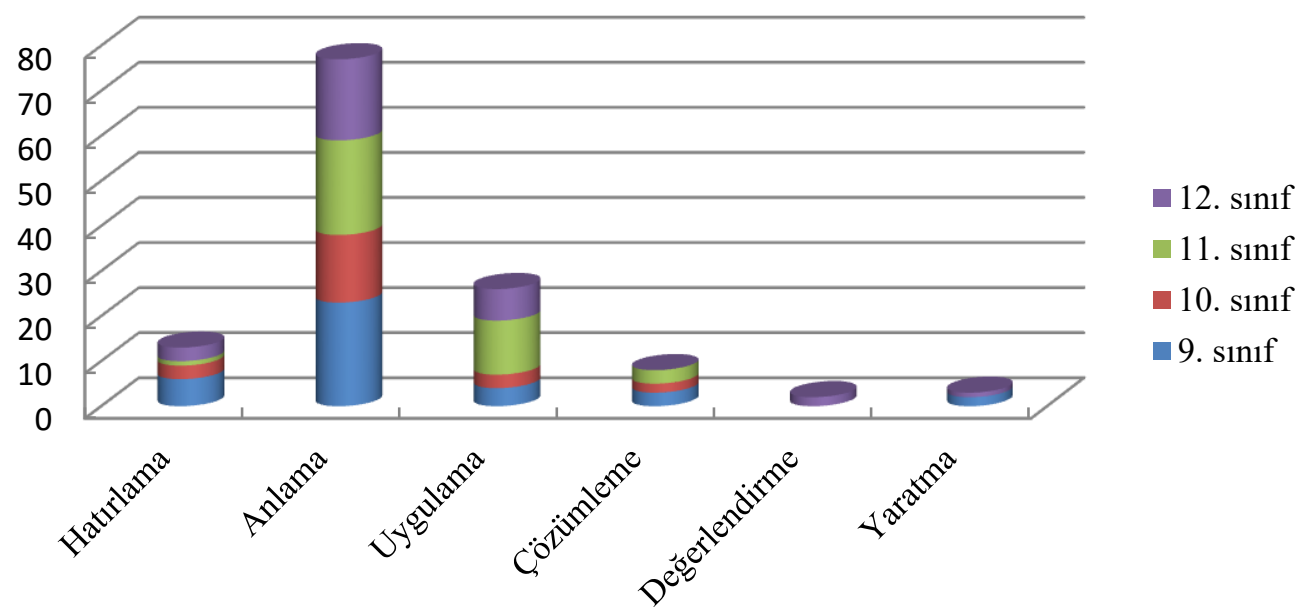

Fig. 6. Taslak Ortaöğretim Kimya Dersi Öğretim Programı Kazanımlarının Bilişsel Süreç Boyutu Alt Basamaklarına Göre Dağılımı

Ortaöğretim Kimya Dersi Öğretim Programı'nda yer alan kazanımların yenilenmiş Bloom taksonomisi bilişsel süreç boyutu alt basamaklarına göre dağılımı (Fig. 6) yer almaktadır. Ortaöğretim Kimya Dersi Öğretim Programı'nı kazanımlarının genel olarak bilişsel süreç boyutu basamaklarına homojen olarak dağılmadığı görülmektedir (Fig. 6). Kazanımların bilgi boyutu basamaklarına ve sınıflar düzeyinde dağılımına bakıldığında da, homojen bir dağılım göstermediği anlaşılmaktadır (Fig. 6).

Kimya Dersi Öğretim Programı kazanımları bilgi boyutu basamaklarına göre değerlendirildiğinde, kazanımların \%10'u hatırlama, \%60'1 anlama, \%20'si uygulama, \%6's1 çözümleme, \%1'i değerlendirme ve \%3'ü yaratma düzeyindedir. Buna göre programda bilişsel süreç boyutlarından en az değerlendirme, en çok ise anlama düzeyinde kazanımının olduğu belirlenmiştir (Fig. 6). 


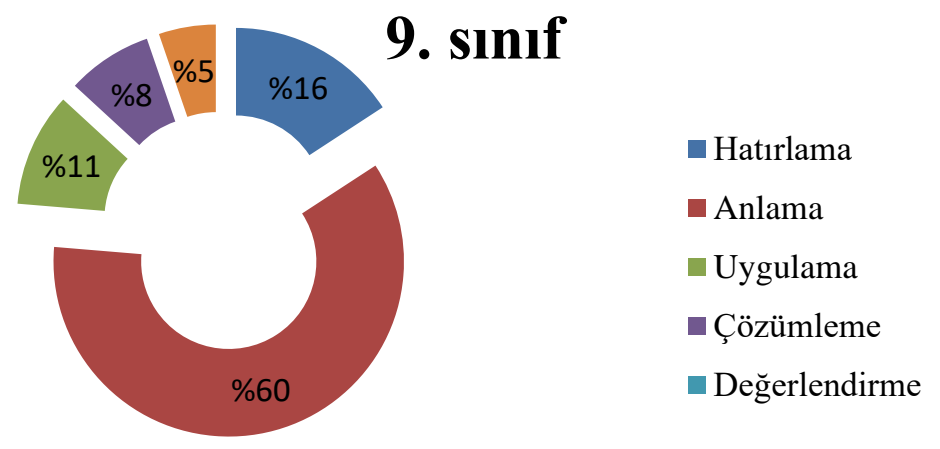

Fig. 7. Taslak Ortaöğretim Kimya Dersi Öğretim Programı 9. Sınıf Kazanımlarının Bilişsel Süreç Boyutu Alt Basamaklarına Göre Yüzde Dağılımı

9. sınıf kazanımlarının \%16'sı hatırlama, \%60'ı anlama, \%11'i uygulama, \%8'i çözümleme ve $\% 5$ 'i yaratma düzeyindedir. 9. Sınıf kazanımlarında en çok anlama düzeyindeki kazanımlara yer verilirken değerlendirme düzeyinde kazanım bulunmamaktadır (Fig. 7).

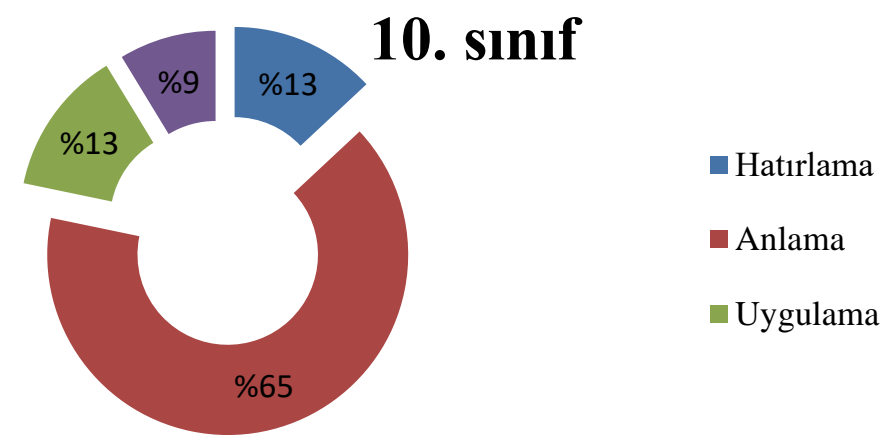

Fig. 8. Taslak Ortaöğretim Kimya Dersi Öğretim Programı 10. Sınıf Kazanımlarının Bilişsel Süreç Boyutu Alt Basamaklarına Göre Yüzde Dağılımı

10. sınıf kazanımlarının \%13'ü hatırlama, \%65'i anlama, \%13'ü uygulama ve \%9'u çözümleme düzeyindedir (Fig. 8). 10. sınıf kazanımlarında en çok anlama düzeyindeki kazanımlara yer verilmiştir. Fakat değerlendirme ve yaratma basamaklarına yönelik kazanımlar programda yer almamaktadır.

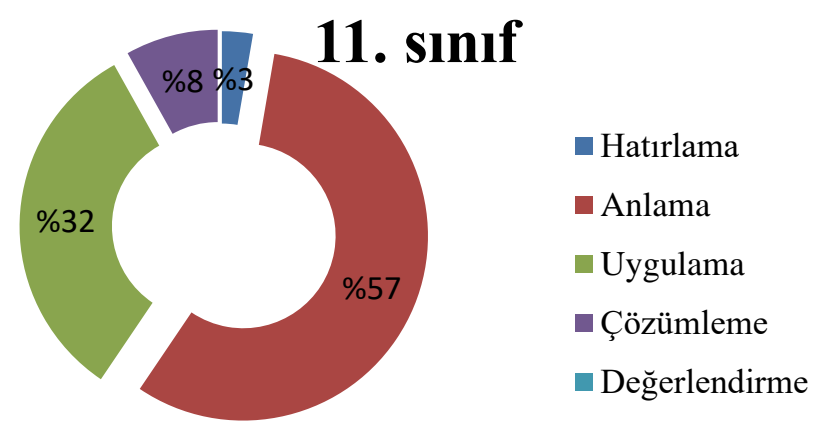

Fig. 9. Taslak Ortaöğretim Kimya Dersi Öğretim Programı 11. Sınıf Kazanımlarının Bilişsel Süreç Boyutu Alt Basamaklarına Göre Yüzde Dağılımı

11. sınıf kazanımlarının \%3'ü hatırlama, \%57'si anlama, \%32'si uygulama ve \%8'i çözümleme düzeyindedir (Fig. 9). 11. sınıf kazanımlarında en çok anlama düzeyindeki kazanımlara yer verilirken değerlendirme ve yaratma düzeyinde kazanım bulunmamaktadır. 




Fig. 10. Taslak Ortaöğretim Kimya Dersi Öğretim Programı 12. Sınıf Kazanımlarının Bilişsel Süreç Boyutu Alt Basamaklarına Göre Yüzde Dağılımı

12. sınıf kazanımlarının \%10'u hatırlama, \%58'i anlama, \%23'ü uygulama, \%6's1 değerlendirme ve \%3'ü yaratma düzeyindedir (Fig. 10). 12. sınıf kazanımlarında en çok anlama düzeyindeki kazanımlara yer verilirken çözümleme düzeyinde kazanım yer almamaktadır.

\section{Sonuç, Tartışma ve Öneriler}

2017 Taslak Ortaöğretim Kimya Dersi Öğretim Programı kazanımlarının, yenilenmiş Bloom taksonomisi analiz sonuçları 'Bilgi boyutu basamaklarına göre Kimya Dersi Öğretim Programı kazanımlarının genel değerlendirilmesi', 'Bilgi boyutu basamaklarına göre Kimya Dersi Öğretim Programı kazanımlarının sınıf düzeyinde değerlendirilmesi', 'Kimya Dersi Öğretim Programı kazanımlarının bilişsel süreç boyutu basamaklarına göre genel değerlendirilmesi' ve 'Kimya Dersi Öğretim Programı kazanımlarının bilişsel süreç boyutu basamaklarına göre sınıf düzeyinde değerlendirilmesi' boyutları dikkate alınarak 4 boyutta açıklanmıştır. Çalışma kapsamında, program analizlerinin genel durumunu bütünsel olarak değerlendirilmesi amaciyla sınıf düzeylerine göre yapılan analizlerin değerlendirilmesi de yapılmıştır (Anderson \& Krathwohl 2010).

Bilgi boyutu basamakları dikkate alınarak yapılan analiz sonuçlarına göre program kazanımların \%85'ini kavramsal bilgi ve üstü düzeydeki kazanımlar oluşturmaktadır. Çalışmanın bilgi basamağı düzeyine göre genel eğiliminin kavramsal bilgi ve üstü düzeyde kazanımlar içermesi alanyazında yer alan çalışmalarla (Gezer et al. 2014; Zorluoğlu et al. 2016; Zorluoğlu et al. 2017; Yaz \& Kurnaz 2017) paralellik göstermektedir. Bu durum 2017 Taslak Ortaöğretim Kimya Dersi Öğretim Programı kazanımlarının öğretimi destekleyeceği ve öğrencilerin bu program sayesinde üst düzey bilgi boyutlarında öğrenme sağlayacağını düşündürmektedir. Çünkü öğretim programlarında yer alan kazanımların kavramsal bilgi ve üstü düzeyde olması öğretimin etkililiğini arttırmakta ve öğrencilerin üst düzey öğrenmelerini geliştirmektedir (Anderson \& Krathwohl 2001). Öğretim programlarının genel eğilimlerinin ayrıntısına inildikçe, var olan eğilimin aksine durumun daha farklı olduğu durumlar açığa çıkmaktadır. Bu gibi durumların yaşanmaması için kapsamlı değerlendirme yapılarak, öğretim boyutuna ve sınıf düzeylerindeki analiz eğilimlerine bakılması gerekmektedir. $\mathrm{Bu}$ durum, araştırmacılara öğretim programları hakkında daha ayrıntılı bilgi sağlamasına yardımcı olacaktır (Anderson \& Krathwohl 2001; Zorluoğlu et al. 2016). Bu bağlamda, Taslak Ortaöğretim Kimya Öğretim Programı kazanımlarının 9.-12. sınıflar düzeyindeki analizleri de değerlendirilerek genel sonuçla karşılaştırılmaya çalışılmıştır.

Bilgi boyutu basamaklarına göre yapılan analizde, program kazanımlarının \%85'ini kavramsal bilgi ve üstü düzeydeki kazanımlar oluşturmasına rağmen, sınıf düzeyinde bu oranlar 
farkl11ık göstermektedir. Örneğin 10. sınıf düzeyinde $\% 87$ kavramsal bilgi ve $\% 13$ olgusal bilgi düzeyinde kazanım yer alırken, işlemsel bilgi ve üstbilişsel bilgiye yönelik hiçbir kazanım bulunmamaktadır. 11. sınıfta ise \%81 kavramsal bilgi ve \%19 işlemsel bilgi düzeyinde kazanım yer alırken olgusal ve üstbilişsel bilgi düzeyinde kazanım yer almamaktadır. Öğrenmenin etkililiğini arttırmak için kazanım düzeylerinin öğretim programlarına homojen olarak dağılması, üst sınıflara gidildikçe üst düzey bilgi basamakları içeren kazanımların daha fazla olması ya da kazanımların sınıf düzeyinde genel olarak kavramsal bilgi düzeyinde olması gerekmektedir (Anderson \& Krathwohl 2001). Çünkü kavramsal bilgiye yönelik hazırlanan kazanımlar olgu/lar hakkındaki bilginin nasıl düzenlendiği veya bu olgu/ların birbiriyle ilişkisi hakkında bireyin sahip olması gereken bilgileri içermektedir (Demirel 2012). Bu nedenle öğretim programlarının en az kavramsal bilgi düzeyinde hazırlanması, öğrencilerin kavramlar hakkında bilgi sahibi olmasına ve kavramların anlamlı öğrenilmesine destek sağlayacaktır. Ayrıca etkili öğretimin sağlanılması için her bilgi düzeyinde kazanımlara yer verilmesi gerekmektedir.

Bilişsel süreç boyutu basamakları dikkate alınarak yapılan analiz sonuçlarına göre, program kazanımların \%90'ı anlama ve üstü düzeydeki kazanımlar oluşturmaktadır. Çalışmanın bilişsel süreç basamağı düzeylerine göre genel eğilimin anlama ve üstü düzeyde kazanımlar içermesi programın öğrenmede öğrenciyi aktif kılacağı ve öğretimin öğrenci merkezli olacağını düşündürmektedir. Çünkü bir programda üst düzey bilişsel süreç boyutu olan çözümleme, değerlendirme ve yaratma düzeylerine yönelik kazanımların varlığı, öğrencinin öğrenmede aktif rol üstlenmesini sağlamaktadır (Crowe et al. 2008). Bu nedenle öğretim programları kazanımlarında üst düzey bilişsel süreçlere yer verilmesi, sorgulayarak öğrenen öğrencilerin yetişmesi sağlayacaktır. Fakat öğretim programı kazanımlarının genel eğilimleri, bir bütündeki parçaları göz ard1 etmeye sebep olabilmektedir (Anderson \& Krathwohl 2001). Çalışma kapsamında genel eğilim anlama düzeyinde olduğunu ve üst düzey bilişsel süreç boyutu basamaklarına da yer verildiğini göstermektedir. Fakat özellikle 10. ve 11. sınıf düzeylerine bakıldığında üst düzey bilişsel süreç boyutu olan değerlendirme ve yaratma basamaklarına yer verilmediği görülmektedir. $\mathrm{Bu}$ durum ise 10 . ve 11. sınıf düzeyindeki kazanımların üst düzey bilişsel becerileri öğrenciye kazandırmada yetersiz olduğunu ya da üst düzey bilişsel becerilerin kazandırılmasında öğretmen yeterliklerinin devreye girmesi gerektiğini düşündürmektedir.

Anderson ve Krathwohl (2001), öğretim programların yer alan kazanımların hatırlama ve anlama düzeyinde daha çok olacağ 1 ve kazanım yazmanın zorluğuna bağlı olarak uygulama, çözümleme ve yaratma düzeylerindeki kazanımlara göre sayıca az olacağını belirtmektedir. $\mathrm{Bu}$ durum dikkate alındığında 2017 Taslak Ortaöğretim Kimya Dersi Öğretim Programı'nda uygulama, çözümleme ve yaratma düzeylerindeki kazanımların sayısının kabul edilebilir bir durum olduğu ortaya çıkmaktadır. Türk, Ünsal ve Karadağ (2016) uygulama, çözümleme ve yaratma düzeylerindeki kazanımların fazla olmamasının normal karşılanabildiğini, ayrıca başka ülkelerin programlarında bilişsel süreç basamaklarının daha dengeli dağıldığını belirtmişlerdir. Türkiye dışındaki ülke programlarında bilgi ve bilişsel süreç boyutu basamaklarının dengeli dağılımı Türkiye'de geliştirilen öğretim programlarını kazanımlarının neden dengeli dağılmadığı sorusunu düşündürmektedir. Dengeli dağılım göstermeme durumunun ise farklı nedenlere bağlı olarak gerçekleşebileceğini düşündürmektedir: (1) Kazanımının orta düzeyde bilgi ve bilişsel süreç becerilerini kapsayacak şekilde hazırlanarak öğretimin öğretmen yaratıcılığına bırakılması (Anderson \& Krathwohl 2001), (2) kazanımın her düzeyde öğrenciye hitap etmesini sağlaması (Anderson \& Krathwohl 2001), (3) kazanım yazılmadan önce hangi düzeyde kazanım yazılacağına karar verilmeyip konu içeriğine göre kazanımların yazılması, (4) kazanımlar yazılırken ya da yazımı bitirildikten sonra kazanımların farklı taksonomilere göre 
nasıl bir eğilim gösterdiğinin belirlenmemesi. $\mathrm{Bu}$ gibi durumların önlenmesi amacıyla kazanımların yenilenmiş Bloom taksonomisi ya da farklı taksonomi basamaklarına dengeli dağılmasının sağlanması için kazanımlar yazılmadan önce, sınıf düzeylerinde taksonomilerin hangi düzeylerinde kazanımların kazandırılması gerektiğine karar verilebilir ya da taksonomilere göre dengeli dağılımın sağlanması için farklı düzeylerde kazanımların bulunacağı bir kazanım havuzu oluşturulabilir. Örneğin bir kazanım yenilenmiş Bloom taksonomisine göre bilgi boyutunda olgusal, kavramsal, işlemsel ve üstbilişsel düzeyde hazırlanabilir ve eksik olan düzeyde kazanım bu havuzdan sağlanabilir. Bu sayede kazanımların programlarda homojen dağglımı sağlanabilir. Ayrıca öğretim programlarında, bilişsel süreç boyutu basamaklarından çözümleme, değerlendirme ve yaratma basamaklarına daha fazla yer verilmesi, öğrencilerin eleştirel düşünme, problem çözme ve yaratıcı düşünme gibi üst düzey düşünme becerilerinin geliştirilmesine yardımcı olacaktır.

\section{KAYNAKÇA}

Akaygün S., Elmas R., Kara H., Karataş F. Ö. \& Yıldırım G. (2016). "Fen Lisesi Kimya Öğretmenlerinden Bir Yansıtma: Güncellenen Kimya Öğretim Programı ile İlgili Görüşler”. Journal of Education Faculty 18/2 (2016) 737-770.

Amer A. (2006). "Reflections on Bloom's Revised Taxonomy". Electronic Journal of Research in Educational Psychology 4/8 (2006) 213-230.

Anderson L. W. (2005). "Objectives, Evaluation, and the Improvement of Education". Studies in Educational Evaluation 32 (2005) 102-113.

Anderson L. W. \& Krathwohl D. R. (Eds.). (2001). Taxonomy for Learning, Teaching and Assessing: A Revision of Bloom's Taxonomy of Educational Objectives. Needham Heights, MA 2001.

Anderson L.W. \& Krathwohl D. R. (2010). Öğrenme Öğretim ve Değerlendirme ile İlgili Bir Sintflama. Çev. D. A. Özçelik. Ankara 2010.

Ayas A. (1995). "Fen Bilimlerinde Program Geliştirme ve Uygulama Teknikleri Üzerine Bir Çalışma: İki Çağdaş Yaklaşımın Değerlendirilmesi”. Hacettepe Üniversitesi Eğitim Fakültesi Dergisi 11 (1995) 149155.

Ayas A., Çepni S., Johnson D. \& Turgut M. (1997). Kimya Öğretimi, Öğretmen Eğitimi Dizisi. Ankara 1997.

Bloom B. S. (1956). Taxonomy of Educational Objectives, The Classification of Educational Goals, Handbook I: Cognitive Domain. New York 1956.

Bowen A. G. (2009). "Document Analysis as a Qualitative Research Method". Qualitative Research Journal 9/2 (2009) 27-40.

Crowe A., Dirks C. \& Wenderoth M. P. (2008). "Biology in Bloom: Implementing Bloom's Taxonomy to Enhance Student Learning in Biology". CBE Life Sciences Education 7 (2008) 368-381.

Demirel Ö. (2012). Eğitimde Program Geliştirme: Kuramdan Uygulamaya. Ankara 2012.

Doğanay A. \& Sarı M. (2007). Öğretim Amaçlarının Belirlenmesi, Ifade Edilmesi ve Uygun İçeriğin Seçilmesi. Ankara 2007.

Ekiz D. (2008). Öğretimle İlgili Temel Kavramlar ve Program Geliştirme. Trabzon 2008.

Glesne C. (2013). Nitel Araştırmaya Giriş. Ankara 2013.

Gezer M., Şahin İ., Sünkür M. Ö. \& Meral E. (2014). "8. Sınıf Türkiye Cumhuriyeti İnkılâp Tarihi ve Atatürkçülük Dersi Kazanımlarının Revize Edilmiş Bloom Taksonomisine Göre Değerlendirilmesi”. Bartın Üniversitesi Ë̆itim Fakültesi Dergisi 3/1 (2014) 433-455.

Karasar N. (2008). Bilimsel Araştırma Yöntemi. Ankara 2008.

Krathwohl D. R. (2009). "Bloom Taksonomisinin Revizyonu: Genel Bir Bakış”. İlköğretim Online 8/3 (2009) 1-7.

Krathwohl D. R. (2002). “A Revision of Bloom's Taxonomy: An Overview”. Theory Into Practice 41/4 
(2002) 212-218.

Mayer R. E. (2002). "Rote Versus Meaningful Learning”. Theory Into Practice 41/4 (2002) 224-232.

M. E. B. (2017). Taslak Ortä̈ğretim Kimya Dersi Öğretim Programı. Kaynak: http://mufredat.meb.gov.tr adresinden alınmıştır.

Pamuk F. (1988). Genel kimya. Ankara 1988.

Özdemir M., Altık S. \& Baki N. (2015). "Bloom’un Yenilenmiş Taksonomisine Göre Sosyal Bilgiler Öğretim Programı Kazanımlarının İncelenmesi”. Ĕgitim ve Öğretim Araştırmaları Dergisi 4/3 (2015) 363-375.

Sönmez V. (2007). Program Geliştirmede Öğretmen Elkitabı. Ankara 2007.

Tutkun Ö. F., Demirtaş Z., Arslan S. \& Erdoğan D. (2015). "Revize Bloom Taksonomisinin Genel Yapısı: Gerekçeler ve Değişiklikler”. The Journal of Academic Social Science Studies 32/3 (2015) 57-62.

Türk O., Ünsal Y. \& Karadağ M. (2016). "Kanada, Singapur ve 2013 Türkiye Fizik Öğretim Programlarının İçerik ve Kazanımlar Açısından Karşılaştırılması”. Eğitim ve Toplum Araştırmaları Dergisi 3/2 (2016) 31-46.

Yaz Ö. V. \& Kurnaz M. A. (2017). “2013 Fen Bilimleri Öğretim Programının İncelenmesi”. Uluslararası Türk Eğitim Bilimleri Dergisi 5/8 (2017) 173-184.

Yıldırım A. \& Şimşek H. (2011). Sosyal Bilimlerde Nitel Araştırma Yöntemleri. Ankara 2011.

Yüksel S. (2007). "Bilişsel Alanın Sınıflamasında (Taksonomi) Yeni Gelişmeler ve Sınıflamalar”. Türk Eğitim Bilimleri Dergisi 5/3 (2007) 479-509.

Zorluoğlu S. L., Şahintürk A. \& Bağrıyanık K. E. (2017). "2013 Yılı Fen Bilimleri Öğretim Programı Kazanımlarının Yenilenmiş Bloom Taksonomisine Göre Analizi ve Değerlendirilmesi”. Bartın Üniversitesi Ĕ̈itim Fakültesi Dergisi 6/1 (2017) 1-15.

Zorluoğlu L., Kızılaslan A. \& Sözbilir M. (2016). "Ortaöğretim Kimya Dersi Öğretim Programı Kazanımlarının Yapılandırılmış Bloom Taksonomisine Göre Analizi ve Değerlendirilmesi”. Necatibey Eğitim Fakültesi Elektronik Fen ve Matematik Eğitimi Dergisi 10/1 (2016) 260-279. 